\title{
Microbial risk assessment of ready-to-eat fast foods from different street-vended restaurants
}

\author{
Abdullah Al Momen Sabuj, Zobayda Farzana Haque, Md. Iftekhar Younus, Amrita Pondit, Nanda Barua,
} Md. Golzar Hossain (D), Md. Alimul Islam and Sukumar Saha

\author{
Department of Microbiology and Hygiene, Faculty of Veterinary Science, Bangladesh Agricultural University, \\ Mymensingh-2202, Bangladesh. \\ Corresponding author: Sukumar Saha, e-mail: sukumar.saha@bau.edu.bd \\ Co-authors: AAMS: sabuj0010@gmail.com, ZFH: zobayda1143@gmail.com, \\ MIY: iftekharvet08@gmail.com, AP: amritapondit33@gmail.com, NB: nanda.barua1@gmail.com, \\ MGH: mghossain@bau.edu.bd, MAI: alim_bau@yahoo.co.in \\ Received: 05-12-2019, Accepted: 09-03-2020, Published online: 03-05-2020
}

doi: www.doi.org/10.14202/IJOH.2020.41-48 How to cite this article: Sabuj AAM, Haque ZF, Younus MI, Pondit A, Barua N, Hossain MG, Islam MA, Saha S (2020) Microbial risk assessment of ready-to-eat fast foods from different street-vended restaurants, Int. J. One Health, 6(1): 41-48.

\begin{abstract}
Aim: Microbiological risk analysis of ready-to-eat fast foods for sale on the campus of Bangladesh Agricultural University was undertaken to understand the contribution of such foods to foodborne disease.

Materials and Methods: From each of 10 randomly selected fast food outlets, a total of 120 samples of six food items were collected to assess common microbial load. In parallel, vendors were asked about their food production and selling practices, while consumers $(n=200)$ were asked about their consumption of fast foods and whether they had experienced symptoms of foodborne disease.

Results: Aerobic plate count (APC) varied from 6.92 to $7.24 \log$ colony-forming unit (cfu)/g, Staphylococcus spp. 4.67 to $5.15 \log \mathrm{cfu} / \mathrm{g}$, Salmonella spp. 3.67 to $4.22 \mathrm{log} \mathrm{cfu} / \mathrm{g}$, and Escherichia coli 4.10 to $4.58 \mathrm{log} \mathrm{cfu} / \mathrm{g}$. Microbial risk assessment of Staphylococcus spp., Salmonella spp., and E. coli for daily, weekly, or monthly consumption was estimated by Monte Carlo simulation (10,000 iterations). The consumer survey showed 57\% chance of being infected by ready-to-eat fast food samples. The calculated mean annual risks of Staphylococcus spp., Salmonella spp., and E. coli infection were about $100 \%$ in all cases.
\end{abstract}

Conclusion: Thus, the study revealed high risk of infection associated with the consumption of ready-to-eat fast foods.

Keywords: fast foods, microbial quality, microbial risk, Monte Carlo simulation.

\section{Introduction}

It has been estimated that foodborne disease affects around 30 million individuals in Bangladesh every year [1], and it has been postulated that "fast food" (i.e., food that has been prepared for direct human consumption without any need for further processing or handling: [2]) contributes significantly to this total. The consumption of fast food is increasing worldwide, largely because it is generally cheap, readily available, convenient, and fits well into an urbanized lifestyle. Bangladesh has experienced rapid societal changes, including urbanization, increased female employment, longer working hours, education, and other causes of absence from home, whose net effect has been a rapid expansion in the number of fast food premises. This increase in the fast food sector has largely occurred without effective regulation of standards of food safety and hygiene [3], with the result

Copyright: Sabuj, et al. This article is an open access article distributed under the terms of the Creative Commons Attribution 4.0 International License (http://creativecommons.org/licenses/ by/4.0/), which permits unrestricted use, distribution, and reproduction in any medium, provided you give appropriate credit to the original author(s) and the source, provide a link to the Creative Commons license, and indicate if changes were made. The Creative Commons Public Domain Dedication waiver (http:// creativecommons.org/ publicdomain/zero/1.0/) applies to the data made available in this article, unless otherwise stated. that, for most people, meals away from home mean various forms of fast food that is prepared and sold at small-scale roadside eateries which are usually unhygienic. Such food is increasingly likely to represent the main meal of the day.

There is a great variety of savory and sweet fast foods available in Bangladesh [4], which are characteristically made from reheated, precooked ingredients, and are served in a packaged form for takeout eating [5]. While most of the ingredients used in manufacturing fast food are nutritious, all have been shown to have the potential to harbor pathogenic organisms, including Staphylococcus aureus, Salmonella spp., Escherichia coli, Enterobacter spp., and Listeria monocytogenes, within the Bangladesh fast food chain [6]. These bacteria are responsible for causing foodborne diseases. A wide variety of illnesses is caused by bacterial, viral, parasitic, and chemical contamination that can occur in an unregulated fast food market.

Ready-to-eat fast foods are, therefore, of great significance in the epidemiology of foodborne disease and are probably a major contributor to the increase in foodborne illness that is taking place throughout the world and turns into an alarming concern involving wide scope of infection caused by the harmful 
microorganisms [7]. Moreover, there is a growing concern for antimicrobial resistance in common bacterial food contaminants. Ahmed et al. [3] have recorded deaths in Bangladesh due to human infection with foodborne bacteria that were resistant to the antibiotics that had been available for the treatment of such infections.

Risk analysis is a useful food safety tool that helps to identify foods or food ingredients that are actually or potentially unsafe, or other hazardous materials and/or practices, to reduce the rate of foodborne disease $[8,9]$. Risk analysis comprises three components: Risk assessment, risk management, and risk communication. Risk assessment estimates adverse effects on human health using pathophysiological and epidemiological methods that relate to potentially hazardous components [8]. More specifically, quantitative microbial risk assessment (QMRA) evaluates the risks that are related to the utilization of a specific food/ ingredient and provides an appraisal of the level of illness that a particular pathogen can cause in a population who are exposed to contaminated food [10].

A preliminary microbial risk assessment of readyto-eat vegetable salads in Bangladesh Agricultural University (BAU) was undertaken by Younus et al. [11], with the key result that $\sim 20 \%$ of students who consumed such salads became infected with at least one foodborne species of bacteria. However, that study was undertaken with relatively small numbers of participants, so more generalizable results need to be developed. At present, around 10,000 students are studying in BAU, most of whom are resident on the campus. This densely-populated campus is serviced by many food vendors and restaurants, who, as with most urban fast food providers, are not subject to stringent food safety and hygiene standards. Using the campus as a model of a dense urban population, and with regard to the results of Younus et al. [11] of the likelihood of food contamination amongst its fast food premises, the opportunity was taken to determine the contribution of restaurant workers to the microbial contamination of fast foods in different restaurants.

The present research was designed to, for fast food premises on the BAU campus: (1) Determine the presence and total viable bacterial load of common bacterial pathogens (with special emphasis on Staphylococcus spp., Salmonella spp., and E. coli and (2) undertake microbial risk assessment of fast food items using Monte Carlo simulation, an exponential predictive model.

\section{Materials and Methods}

\section{Ethical approval and informed consent}

No ethical approval was required; however, during sample collection and survey, verbal permission was taken from restaurant vendors and consumers.

\section{Selection of sampling sites}

The study was carried out in and around the campus of BAU, Mymensingh, Bangladesh, between
January 2017 and December 2017. There are nearly 50 fast food outlets that are distributed in seven major locations around the BAU campus. Two outlets in each of five of these locations were selected for sampling based on the volume of sales and the density of outlets in the location. The sampling program involved (i) microbiological sampling of food that was for sale at these outlets, (ii) a questionnaire-based study of food handling practices, and (iii) verbal questioning of consumers (purchasers) to evaluate the consumption pattern of fast foods.

\section{Microbiological samples}

From each of the 10 selected fast food outlets, at two different time points, six items (i.e., shingara, samosa, piazu, puri, potato chop, and beguni) were acquired as though being purchased and consumed by consumers frequently. Each item (i.e., sample) placed in a labeled sterile polyethylene container and transported on ice to the laboratory. After weighing, the sample was ground in a sterile mortar and pestle. The sample was then mixed with nine volumes of sterile distilled water in a sterile blending machine. Thereafter, serial 10 -fold dilutions $\left(10^{-1}-10^{-6}\right)$ were made from each sample.

Aliquots $(0.1 \mathrm{~mL})$ of each dilution of each sample were inoculated onto microbiological culture media: Nutrient agar, Mannitol salt (MS), SalmonellaShigella (SS), and eosin methylene blue (EMB) agar. After $24 \mathrm{~h}$ of incubation at $37^{\circ} \mathrm{C}$, colonies that were golden-yellow, had a black center or metallic sheen color colonies which were observed in MS, SS, and EMB agar were identified as Staphylococcus spp., Salmonella spp., and E. coli, respectively. After that, 30-300 distinct colonies containing plates of each specific media were counted and recorded as colony-forming unit (cfu)/g of fast food samples.

\section{Evaluation of food handling practices}

General observations were obtained from various restaurants through observational questions to justify the food handling practices conducted by restaurant workers during sales. On each occasion, when food samples were collected, the following observations were made: (i) Types of fast food served in that restaurant; (ii) the area where fast food is stored or kept for sale; (iii) types of utensil used to serve food; and (iv) practice of the food handlers during serving the fast food. Furthermore, vendors were asked about their food handling practices such as: (i) If they reheat the food before sale; (ii) how they manage the leftover food; and (iii) any training received on hygienic food preparation and handling.

\section{Verbal evaluation of fast food consumption patterns}

A total of 200 questionnaires were distributed to consumers comprising 100 males and 100 females from each restaurant randomly, 10 male and 10 female consumers were asked to fill up the questionnaires. They were asked to answer the following questions: (i) How old they were; (ii) how frequently 
they consume fast food; (iii) from which source they consume the fast food; (iv) why they eat fast food; (v) if any disease experienced just after having the fast food; and (vi) what type of disease or discomfort they felt. The questionnaires were collected instantly after they wrote the answers by themselves.

\section{Microbial risk assessment}

Microbial risk assessment comprises the four steps of hazard identification, hazard characterization, exposure assessment, and risk characterization [12]. The microbial risk associated with fast food handling practices in the present study was conducted as described by Amoah [13], as follows.

\section{Hazard identification}

Microbiological risk assessment starts with hazard identification. These hazards were prospectively identified as Staphylococcus spp., Salmonella spp., and $E$. coli contamination of fast food products. These organisms were selected as the model QMRA organisms as they are commonly present in food samples.

\section{Dose-response assessment (hazard characterization)}

Hazard characterization describes the adverse health effects associated consumption of microorganisms using dose-response relationships. An exponential dose-response model [14] was used in this study to predict the probability of Staphylococcus spp., Salmonella spp., and E. coli infection, based on microbial analysis of the selected organism. The equation used for determining the probability of infection is as follows:

$$
P(d)=1-e^{-r d}
$$

Where, $P(d)$ is the probability of infection, $d$ is the dose (cfu) of microorganisms consumed per person per day, and $\mathrm{r}$ is dimensionless infectivity constant. The model parameter " $r$ " used was $7.64 \times 10^{-8}$ for Staphylococcus spp. [14], $3.97 \times 10^{-6}$ for Salmonella spp. [15], and $2.18 \times 10^{-4}$ for E. coli [16].

The final dose (d) of microorganisms consumed by per person per serving was as the product of the weight of food consumed and the quantity of organisms present per gram of food (estimated as 50-70 g per serving, based on serving size and consumers' statements of quantities that they consumed). Separate risks were estimated according to each food item. The final doses of Staphylococcus spp., Salmonella spp., and $E$. coli consumed per serving were inputted into the mathematical model to obtain the probability of infection per day.

\section{Exposure assessment}

This step of microbial risk assessment deals with amount of food consumed and the frequency of consumption of food for a specified period of time to evaluate the consumer's exposure to microorganisms associated with particular food with a defined period. Three exposure scenarios were estimated, namely, frequent (daily), average (weekly), or occasional (monthly) consumption of each fast food type, as described by Amoah [13].

\section{Risk characterization}

This step integrates the previous three steps and estimates the probability of infection in resulting from exposure to hazards in every scenario. The annual probability of infection for each scenario was calculated from the probability of infection and the number of days of exposure within the year.

$$
\mathrm{P}_{\mathrm{ann}}=1-\{1-\mathrm{P}(\mathrm{d})\}^{\mathrm{n}}
$$

Where, $\mathrm{n}$ is the number of days of exposure within the year.

\section{Statistical analysis}

Data were entered into SPSS 25.0 (IBM Corporation, USA) for descriptive analysis. One-way ANOVA was performed to compare difference among the foods and statistical significance of difference between means was tested at $95 \%$ confidence level $(p<0.05)$ by Tukey's multiple test [17]. For each of the exposure scenarios, a Monte Carlo simulation was run using Microsoft Excel at risk software version 7.5.0 (Palisade Corporation) sampling 10,000 iterations to determine the annual risk of infection for each exposure scenario.

\section{Results}

\section{Basic data}

The average microbial load of all fast food items is shown in Table-1. The highest aerobic plate count (APC) was present in piazu samples $(7.24 \log \mathrm{cfu} / \mathrm{g}$ ) and the lowest in samosa samples (6.92 log cfu/g). Staphylococcus spp. count was highest in puri samples (5.15 log cfu/g) and lowest in beguni samples (4.67 log cfu/g). The highest and lowest E. coli counts were present in puri and piazu samples (4.58 log cfu/g vs. $4.10 \log \mathrm{cfu} / \mathrm{g}$ ), respectively. The highest Salmonella spp. count (4.22 log cfu/g) was present in samosa samples and the lowest (3.67 log cfu/g) in shingara samples. The average mean difference of APC, Staphylococcus spp., E. coli, and Salmonella spp. among all ready-to-eat fast food items was not statistically significant $(\mathrm{p}<0.05)$, but the significant differences were observed in individual food items among the selected restaurants.

All six fast food items were prepared by the majority of the outlets. Handling practices utilized by outlet workers are summarized in Table-2. Key results were that food was stored in an open place in environmental temperature $\left(30-40^{\circ} \mathrm{C}\right)$ in $72 \%$ of outlets; shared utensils were utilized to serve all of the different types of food; workers did not use gloves for handling food; leftover food was sold on the next day by all outlets, and workers had not received any training on hygienic food preparation and handling. On the other hand, none of the outlets reheated food before the sale. 
Table-1: Average microbial load of all ready-to-eat fast food samples.

\begin{tabular}{lcccc}
\hline Item $(\mathbf{n = 1 2 0})$ & \multicolumn{4}{c}{ Microbial load (log cfu/g \pm SD) } \\
\cline { 2 - 5 } & APC & Staphylococcus spp. & Salmonella spp. & Escherichia coli \\
\hline Shingara $(n=20)$ & $7.12 \pm 0.42$ & $4.69 \pm 0.61$ & $3.67 \pm 0.10$ & $4.28 \pm 0.56$ \\
Samosa $(n=20)$ & $6.92 \pm 0.45$ & $4.77 \pm 0.70$ & $4.22 \pm 0.64$ & $4.52 \pm 0.39$ \\
Piazu $(n=20)$ & $7.24 \pm 0.09$ & $4.71 \pm 0.33$ & - & $4.10 \pm 0.54$ \\
Puri $(n=20)$ & $6.96 \pm 0.44$ & $5.15 \pm 0.44$ & $3.96 \pm 0.47$ & $4.58 \pm 0.50$ \\
Potato chop $(n=20)$ & $7.03 \pm 0.59$ & $4.84 \pm 0.03$ & $4.07 \pm 0.55$ & $4.35 \pm 0.54$ \\
Beguni $(n=20)$ & $6.94 \pm 0.50$ & $4.67 \pm 0.62$ & $4.04 \pm 0.46$ & $4.20 \pm 0.40$ \\
\hline
\end{tabular}

According to the International Commission for Microbiological Specifications for Foods (ICMSF, 2002), acceptable ranges of APC, Staphylococcus, and Escherichia coli are $10^{6} \mathrm{cfu} / \mathrm{g}(6 \mathrm{log} \mathrm{cfu} / \mathrm{g}), 10^{4} \mathrm{cfu} / \mathrm{g}(4 \mathrm{log} \mathrm{cfu} / \mathrm{g})$, and $10^{2} \mathrm{cfu} / \mathrm{g}(2 \mathrm{log} \mathrm{cfu} / \mathrm{g})$, respectively, and detection of any Salmonella spp. in a $25 \mathrm{~g}$ sample is unacceptable. APC=Aerobic plate count, cfu=Colony-forming unit, $\mathrm{SD}=$ Standard deviation

Table-2: Fast food handling practice details.

\begin{tabular}{llcc}
\hline Parameter & Parameter & Frequency (n=50) & Percentage \\
\hline Types of fast foods & Shingara & 50 & 100 \\
& Samosa & 50 & 100 \\
& Piazu & 44 & 88 \\
& Puri & 50 & 100 \\
Fast food store or kept for sale & Potato chop & 44 & 68 \\
Utensil used to serve food & Beguni & 36 & 80 \\
& Open place & 14 & 72 \\
Fast food served by food handlers & Enclosed area & 0 & 28 \\
& Designated serving utensil & 50 & 0 \\
Reheat food before sale & Shared utensil & 0 & 100 \\
& Gloves protected hand & 50 & 0 \\
Management of leftover food & Bare hand & 0 & 100 \\
& Yes & 50 & 0 \\
Any training received on hygienic food & No & 0 & 100 \\
preparation and handling & Throw it away & 0 & 0 \\
\hline
\end{tabular}

Fast food consumption data are summarized in Table-3. The majority (53.5\%) of respondents were between 20 and 25 years of age, and most consumed fast foods from on-campus outlets $(51.5 \%)$ or university canteens $(43.5 \%)$. Fast foods were consumed every day by $31 \%$ of the respondents, $42 \%$ once per week, and $18.5 \%$ once per month. A total of $61 \%$ of respondents had experienced disease that they associated with eating fast foods. Of these, gastric reflux/ abdominal cramp, not associated with vomiting, was reported by $31 \%$ of respondents.

Overall, there was $57 \%$ chance of being infected by fast food items consumed by total consumers. Among these, males had $49 \%$ chance and females had $67 \%$ chance of being infected. Frequent consumers (daily) had a higher chance $(63 \%)$ of becoming infected than other type of consumers. Respondents aged between 25 and 30 years of age had a higher chance $(58 \%)$ of being infected after consumption of fast food items in relation to the respondents below 20 years of age (Table-4).

\section{Risk analysis}

Staphylococcus spp.

The dose-response assessment after Monte Carlo simulation showed that the mean probability of Staphylococcus spp. infection was 78\% (90\% confidence interval [CI]: 4-234\%) in puri samples (highest) versus $24 \%$ (90\% CI: $1-71 \%$ ) in piazu samples (lowest). The mean annual risk of Staphylococcus spp. infection was similar for all three consumption frequencies (daily, weekly, and monthly) at $110 \%$, with minimum and maximum risk ranging from $100 \%$ to $213 \%$ (Table-5). The result demonstrates that approximately 110 out of 100 consumers had a chance of getting an infection with Staphylococcus spp. after consumption of fast food, regardless of the frequency of consumption.

\section{Salmonella spp.}

The probability of Salmonella spp. infection highest at 99\% (90\% CI: 5-296\%) in samosa and potato samples versus other food items (for example, the probability for shingara samples was $77 \%[90 \%$ CI: 4-234\%]). The annual risk of Salmonella spp. infection did not differ between exposure frequencies: The annual probability infection of Salmonella spp. was $110 \%$ in frequent, average, and occasional consumers, in whom the risk of infection varied from $100 \%$ to $226 \%$ (Table-6). 
Table-3: Fast food consumption details.

\begin{tabular}{|c|c|c|c|c|c|}
\hline \multirow[t]{2}{*}{ Parameter } & \multirow[t]{2}{*}{ Consumer } & \multicolumn{3}{|c|}{ Distribution of respondents } & \multirow[t]{2}{*}{ Percentage } \\
\hline & & Male $(n=100)$ & Female $(n=100)$ & Total $(n=200)$ & \\
\hline \multirow[t]{3}{*}{ Age } & Below 20 & 27 & 10 & 37 & 18.5 \\
\hline & $20-25$ & 40 & 67 & 107 & 53.5 \\
\hline & $25-30$ & 33 & 23 & 56 & 28.0 \\
\hline \multirow{4}{*}{$\begin{array}{l}\text { Fast food consumption } \\
\text { frequency }\end{array}$} & Every day & 37 & 25 & 62 & 31.0 \\
\hline & Once in week & 36 & 48 & 84 & 42.0 \\
\hline & Once in month & 17 & 20 & 37 & 18.5 \\
\hline & Unspecified & 10 & 7 & 17 & 8.5 \\
\hline \multirow{4}{*}{$\begin{array}{l}\text { Source from which fast } \\
\text { food is consumed }\end{array}$} & Home & 3 & 3 & 6 & 3.0 \\
\hline & Restaurants & 57 & 46 & 103 & 51.5 \\
\hline & Canteen & 37 & 50 & 87 & 43.5 \\
\hline & Others & 3 & 1 & 4 & 2.0 \\
\hline \multirow{5}{*}{$\begin{array}{l}\text { Reason for eating fast } \\
\text { food }\end{array}$} & Health benefits & 0 & 1 & 1 & 0.5 \\
\hline & Taste & 85 & 71 & 156 & 78.0 \\
\hline & Esthetic appeal & 9 & 12 & 21 & 10.5 \\
\hline & Social interaction & 4 & 8 & 12 & 6.0 \\
\hline & Others & 1 & 9 & 10 & 5.0 \\
\hline \multirow[t]{2}{*}{ Disease experienced } & Yes & 55 & 67 & 122 & 61.0 \\
\hline & No & 45 & 33 & 78 & 39.0 \\
\hline \multirow[t]{5}{*}{ Types of diseases } & Acidity & 24 & 38 & 62 & 31.0 \\
\hline & Vomiting & 1 & 9 & 10 & 5.0 \\
\hline & Abdominal discomfort & 14 & 12 & 26 & 13.0 \\
\hline & Others & 16 & 8 & 24 & 12.0 \\
\hline & None & 45 & 33 & 78 & 39.0 \\
\hline
\end{tabular}

Table-4: Risk assessment of consumers according to different parameter.

\begin{tabular}{|c|c|c|c|c|c|}
\hline Parameter & Consumers & Number of consumers ( $n$ ) & Case findings (d) & Risk (d/n) & Percentage \\
\hline \multirow[t]{2}{*}{ Sex } & Male & 57 & 28 & 0.49 & 49 \\
\hline & Female & 46 & 31 & 0.67 & 67 \\
\hline \multirow[t]{4}{*}{ Type of consumers } & Frequent & 32 & 20 & 0.63 & 63 \\
\hline & Average & 38 & 22 & 0.58 & 58 \\
\hline & Occasional & 26 & 13 & 0.50 & 50 \\
\hline & Unspecified & 7 & 4 & 0.57 & 57 \\
\hline \multirow[t]{3}{*}{ Age } & $<20$ & 25 & 11 & 0.44 & 44 \\
\hline & $20-25$ & 53 & 30 & 0.57 & 57 \\
\hline & $25-30$ & 25 & 18 & 0.72 & 72 \\
\hline
\end{tabular}

Table-5: Risk assessment of Staphylococcus spp. in all ready-to-eat fast food items.

\begin{tabular}{|c|c|c|c|c|c|}
\hline \multirow{2}{*}{$\begin{array}{l}\text { Ready-to-eat } \\
\text { fast food } \\
\text { items }\end{array}$} & \multirow{2}{*}{$\begin{array}{l}\text { Mean dose of } \\
\text { organisms per } \\
\text { serving (cfu) }\end{array}$} & \multirow{2}{*}{$\begin{array}{c}\text { Mean probability } \\
\text { of infection } \\
(90 \% \mathrm{CI})\end{array}$} & \multicolumn{3}{|c|}{ Mean annual risk of infection $(90 \% \mathrm{CI})$} \\
\hline & & & $\begin{array}{c}\text { Frequent } \\
\text { consumer (daily) }\end{array}$ & $\begin{array}{c}\text { Average } \\
\text { consumer (weekly) }\end{array}$ & $\begin{array}{c}\text { Occasional } \\
\text { consumer (monthly) }\end{array}$ \\
\hline Shingara & $7.73 \times 10^{6}$ & $44(2-131)$ & $110(100-206)$ & $110(100-193)$ & $110(100-200)$ \\
\hline Samosa & $1.15 \times 10^{7}$ & $58(3-174)$ & $110(100-199)$ & $110(100-193)$ & $110(100-197)$ \\
\hline Piazu & $3.60 \times 10^{6}$ & $24(1-71)$ & $110(100-207)$ & $110(100-187)$ & $110(100-200)$ \\
\hline Puri & $2.0 \times 10^{7}$ & $78(4-234)$ & $110(100-192)$ & $110(100-211)$ & $110(100-204)$ \\
\hline Potato chop & $5.98 \times 10^{6}$ & $37(1-110)$ & $110(100-193)$ & $110(100-192)$ & $110(100-206)$ \\
\hline Beguni & $6.01 \times 10^{6}$ & $37(1-110)$ & $110(100-195)$ & $110(100-213)$ & $110(100-187)$ \\
\hline
\end{tabular}

$\mathrm{cfu}=$ Colony-forming unit, $\mathrm{CI}=$ Confidence interval

E. coli

The probability of $E$. coli infection was $100 \%$ in all fast food items, although the CI was wide ( $90 \% \mathrm{CI}$ : $5-300 \%)$. This organism also showed similar results of annual risk of infection to the previous two organisms: Consumers had $110 \%$ chance of becoming infected with $E$. coli after consuming fast food items (Table-7).

\section{Discussion}

The substantive results of this study are, first, that microbiological contamination of fast food samples was widespread and at a high level. All microbiological parameters (APC: 6.9-7.2 log cfu/g, Staphylococcus spp. count: 4.7-5.2 log cfu/g, Salmonella spp. count 3.7-4.2 log cfu/g, and E. coli count: 4.1-4.6 log cfu/g) from all fast food samples were well above the acceptable limits recognized by the International Commission for Microbiological Specifications for Foods [18]. Parallel studies undertaken in other developing countries have shown similar results. Akusu et al. [19], who studied different ready-to-eat fast food samples in Rivers State, 
Table-6: Risk assessment of Salmonella spp. in all ready-to-eat fast food items.

\begin{tabular}{|c|c|c|c|c|c|}
\hline \multirow{2}{*}{$\begin{array}{l}\text { Ready-to-eat } \\
\text { fast food } \\
\text { items }\end{array}$} & \multirow{2}{*}{$\begin{array}{l}\text { Mean dose of } \\
\text { consumption per } \\
\text { serving (cfu) }\end{array}$} & \multirow{2}{*}{$\begin{array}{c}\text { Mean probability } \\
\text { of infection } \\
(90 \% \mathrm{CI})\end{array}$} & \multicolumn{3}{|c|}{ Mean annual risk of infection $(90 \% \mathrm{CI})$} \\
\hline & & & $\begin{array}{c}\text { Frequent } \\
\text { consumer (daily) }\end{array}$ & $\begin{array}{c}\text { Average } \\
\text { consumer (weekly) }\end{array}$ & $\begin{array}{c}\text { Occasional } \\
\text { consumer (monthly) }\end{array}$ \\
\hline Shingara & $3.70 \times 10^{5}$ & $77(4-231)$ & $110(100-206)$ & $110(100-192)$ & $110(100-185)$ \\
\hline Samosa & $1.87 \times 10^{6}$ & $99(5-296)$ & $110(100-194)$ & $110(100-195)$ & $110(100-226)$ \\
\hline Piazu & Not recovered & & & & \\
\hline Puri & $1.02 \times 10^{6}$ & $98(5-294)$ & $110(100-195)$ & $110(100-205)$ & $110(100-202)$ \\
\hline Potato chop & $1.26 \times 10^{6}$ & $99(5-296)$ & $110(100-200)$ & $110(100-197)$ & $110(100-192)$ \\
\hline Beguni & $9.24 \times 10^{5}$ & $97(5-290)$ & $110(100-216)$ & $110(100-200)$ & $110(100-198)$ \\
\hline
\end{tabular}

$\mathrm{cfu}=$ Colony-forming unit, $\mathrm{CI}=$ Confidence interval

Table-7: Risk assessment of Escherichia coli in all ready-to-eat fast food items.

\begin{tabular}{|c|c|c|c|c|c|}
\hline \multirow{2}{*}{$\begin{array}{l}\text { Ready-to-eat } \\
\text { fast food } \\
\text { items }\end{array}$} & \multirow{2}{*}{$\begin{array}{l}\text { Mean dose of } \\
\text { consumption per } \\
\text { serving (cfu) }\end{array}$} & \multirow{2}{*}{$\begin{array}{l}\text { Mean probability } \\
\text { of infection } \\
(90 \% \mathrm{CI})\end{array}$} & \multicolumn{3}{|c|}{ Mean annual risk of infection ( $90 \% \mathrm{CI})$} \\
\hline & & & $\begin{array}{c}\text { Frequent } \\
\text { consumer (daily) }\end{array}$ & $\begin{array}{c}\text { Average } \\
\text { consumer (weekly) }\end{array}$ & $\begin{array}{c}\text { Occasional } \\
\text { consumer (monthly) }\end{array}$ \\
\hline Shingara & $2.37 \times 10^{6}$ & $100(5-300)$ & $110(100-193)$ & $110(100-197)$ & $110(100-266)$ \\
\hline Samosa & $3.0 \times 10^{6}$ & $100(5-300)$ & $110(100-195)$ & $110(100-200)$ & $110(100-197)$ \\
\hline Piazu & $1.22 \times 10^{6}$ & $100(5-300)$ & $110(100-205)$ & $110(100-195)$ & $110(100-194)$ \\
\hline Puri & $5.17 \times 10^{6}$ & $100(5-300)$ & $110(100-192)$ & $110(100-208)$ & $110(100-197)$ \\
\hline Potato chop & $1.97 \times 10^{6}$ & $100(5-300)$ & $110(100-196)$ & $110(100-195)$ & $110(100-215)$ \\
\hline Beguni & $1.25 \times 10^{6}$ & $100(5-300)$ & $110(100-206)$ & $110(100-197)$ & $110(100-202)$ \\
\hline
\end{tabular}

$\mathrm{cfu}=$ Colony-forming unit, $\mathrm{CI}=$ Confidence interval

Nigeria, found the mean viable counts of bacteria, coliforms, and SS on meat-based fast food products were $6.6 \log \mathrm{cfu} / \mathrm{g}, 4.2 \mathrm{log} \mathrm{cfu} / \mathrm{g}$, and $4.3 \mathrm{log} \mathrm{cfu} / \mathrm{g}$, respectively. Adimasu et al. [20] also reported coliforms (4.05 $\log \mathrm{cfu} / \mathrm{g}), S$. aureus (4.17 $\log \mathrm{cfu} / \mathrm{g})$, and Salmonella spp. (4.20 log cfu/g) in street-vended fast food samples in Gondar, Ethiopia. Khandoker et al. [21] noted total viable count ranged from log 4.5 to $5.4 \mathrm{cfu} / \mathrm{g}$, total staphylococcal count ranged from $\log 4.4$ to $5.2 \mathrm{cfu} / \mathrm{g}$, and total coliform count ranged from $\log 1.4$ to $4.3 \mathrm{cfu} / \mathrm{g}$ in spicy puffed rice samples. While there is some variation in actual $\mathrm{cfu}$ counts between studies (perhaps, due to types of foods sampled or to handle and personal hygienic practices during fast foods preparation and serving), it is clear that microbiological contamination of such foods is substantial and significant.

In the present study, $72 \%$ restaurants kept or stored food in the open place in environmental temperature $\left(30-40^{\circ} \mathrm{C}\right)$ favorable for microbial growth, shared utensils were used to serve foods without proper cleaning, restaurant workers did not use any gloves while serving consumers, and none of the restaurant workers had had training on hygienic food preparation and handling practices. These above factors might be caused of increased microbial load in the tested food items. Leftover food was sold in the following day. These trends reflect those of similar investigations. For example, Adimasu et al. [20] in Gondar, Ethiopia, reported that only $16(40 \%)$ participants out of 40 had knowledge about the contamination of fast foods. Likewise, Bereda et al. [22] (Jigjiga City, Ethiopia) also noted that while $59 \%$ of vendors washed food before cooking, $83.3 \%$ used filthy surfaces, and $25 \%$ utilized reused oil for the preparation of food.
Choudhury et al. [23] reported similar findings from Guwahati, Assam, India, where only $37 \%$ of vendors were aware of hygienic food handling and preparation, and few of them were aware of biological sources that are responsible for foodborne diseases.

This level of contamination, together with a lack of awareness about the principles of food hygiene, results in a large proportion of the population being at risk of foodborne disease. Most respondents in the present study consumed fast foods $(43.5 \%$ from canteens and $51.5 \%$ from fast food vendors) and most did so often $(18.5 \%$ at least once a day and $31 \%$ once a week). The high level of major or minor, food-related illnesses confirms the level of risk to the population: $61 \%$ of respondents experienced some form of disease and, even though the most common complaint was "acidity" (31\%), nearly $30 \%$ of respondents also reported more serious diseases such as vomiting or abdominal cramps. The preliminary work of Younus et al. [11] who reported on ready-to-eat vegetables salads in the BAU campus found that 18/88 respondents developed symptoms of foodborne disease after eating such food.

From this study, it was found that the mean annual risks of Staphylococcus spp., Salmonella spp., and $E$. coli infection in all three categories of consumers were $110 \%$ (90\% CI: $100-130 \%$ ) for frequent, average, and occasional consumers. The annual risk of Staphylococcus spp., Salmonella spp., and E. coli infection for frequent, average, or occasional consumers was approximately $10^{1}$ (i.e., 11,11 , and 11 out of 10 ready-to-eat fast food consumers, respectively). In other words, there is $100 \%$ chance of getting infected with these pathogens to all three categories of consumers of fast foods from the tested fast food vendors. 
This figure is very substantially above the level of risk that is acceptable to the WHO $\left(10^{-2}-10^{-4}\right.$ per person per year: [24]).

Women appeared to be at higher risk of developing signs of foodborne disease than men (67\% vs. $49 \%$ ), but biologically-significant result is unclear due to the modest sample size. On the other hand, the higher risk of frequent (daily) than weekly or monthly fast food consumers developing clinical signs (63\%, $58 \%$, and $50 \%$, respectively) does appear to be consistent with the microbiological risk analysis. The age distribution of clinical signs is interesting, in as much as a higher proportion of older (25-30 years old) participants developed clinical signs than did those of younger age groups $(<20$ years: $35 \%, 20-25$ years: $48 \%$, and $25-30$ years: $63 \%$ ).

Taken together, there is an interesting dichotomy between the risk found after determining the dose $(\mathrm{cfu} / \mathrm{g})$ of fast foods using Monte Carlo simulation and the reported proportion of participants who developed foodborne illnesses. On the one hand, there was an immense number of potentially pathogenic microorganisms found in the microbiological analysis and there would be about a $100 \%$ chance of being infected. However, the self-reported risk of clinical illness determined by the questionnaire demonstrated that consumers have only $57 \%$ chance of developing clinical signs associated with eating those fast foods. Presumably, this discrepancy relates to a degree of immunity or resistance to infection in consumers. The findings of our study have to be considered in light of some limitations. First, the sample size was small because of the time limit, and second, we collected samples at a single time point from the fast food outlets. Hence, additional research might be directed toward trying to characterize better the epidemiological associations between food type, level and species of contaminating organisms, and human demographic characteristics in a much larger sample population.

\section{Conclusion}

The present study has demonstrated that fast foods sold in and around the BAU campus are contaminated with common indicator bacteria. Furthermore, the majority of restaurant vendors have had no training in managing food safety and foodborne disease such that there were poor personal hygiene, handling practice, prolong storage of foods in ambient temperature, and selling of leftover food after the following day. Hence, it is necessary to ensure education facilities and food safety training program for all the restaurant vendors that might decrease the risk of infection and deliver safe food. At the same time, consumers should also be aware of the unhygienic facts of fast foods and encourage food vendors to follow the food safety rules and regulations. The most important outcome would be for regular monitoring by the health ministry, with strict law implementation, to enhance the hygienic practices of fast food outlets.

\section{Authors' Contributions}

AAMS and ZFH carried out the research, analyzed the data, and wrote the initial draft of the manuscript. MIY, AP, and NB helped in data collection. MGH contributed to manuscript writing. SS and MAI designed and supervised research work, revised, and finalized the manuscript. All authors read and approved the manuscript before submission.

\section{Acknowledgments}

The authors would like to thank the Ministry of Science and Technology and Ministry of Education, Bangladesh, for funding. Abdullah Al Momen Sabuj was provided with a fellowship from the Ministry of Science and Technology, Bangladesh. The authors are very much grateful to Dr. T. J. Parkinson, School of Veterinary Science, Massey University, New Zealand, for his useful discussions and critical reading of the manuscript.

\section{Competing Interests}

The authors declare that they have no competing interests.

\section{Publisher's Note}

Veterinary World (Publisher of International Journal of One Health) remains neutral with regard to jurisdictional claims in published institutional affiliation.

\section{References}

1. Food and Agricultural Organization. (2012) The State of Food Insecurity in the World 2012. Economic Growth is Necessary But not Sufficient to Accelerate Reduction of Hunger and Malnutrition, Rome, Italy. Available from: http://www.fao.org/3/a-i3027e.pdf. Last accessed on 01-10-2018.

2. Tsang, D. (2002) Microbiological Guidelines for Ready-toEat Food. Road and Environmental Hygiene Department, Hongkong. p115-116.

3. Ahmed, J., Hossain, M.L., Malek, M.A. and Begum, F. (2008) Assessment of bacteriological quality of fast foods and soft drinks in relation to safety and hygiene. Bangladesh J. Microbiol., 25(1): 73-75.

4. Rahman, M., Rahman, M. and Ansary, N. (2014) Safety issues of street foods in Bangladesh. Time J. Biol. Sci. Technol., 2(1): 21-32.

5. Harun, M.A., Ahmed, F. and Maniruzzaman. (2013) Customer hospitality: The case of fast food industry in Bangladesh. World J. Soc. Sci., 3(6): 88-104.

6. Ahmed, S., Tasnim, U.T., Pervin, S. and Islam, M.T. (2014) An assessment of bacteriological quality of some fast food items available in Jessore city and antibiotic susceptibility of isolated Klebsiella spp. Int. J. Biosci., 5(9): 125-130.

7. De Vogli, R., Kouvonen, A. and Gimeno, D. (2014) The influence of market deregulation on fast food consumption and body mass index: A cross-national time series analysis. Bull. World Health Organ., 92(2): 99-107.

8. Duffy, G., Cummins, E., Nally, P., O’Brien, S. and Butler F. (2006) A review of quantitative microbial risk assessment in the management of Escherichia coli O157: H7 on beef. Meat Sci., 74(1): 76-88.

9. Collado, J., Falco, A., Rodrigo, D., Sampedro, F., Pina, M.C. and Martinez, A. (2011) Application of Monte Carlo simulation in industrial microbiological exposure assessment. Applications of Monte Carlo Method in Science and 
Engineering. IntechOpen., UK. p83-94.

10. Forsythe, S.J. (2008) The Microbiological Risk Assessment of Food: John Wiley \& Sons, Inc., America.

11. Younus, M.I., Sabuj, A.A.M., Haque, Z.F., Sayem, S.M., Majumder, S., Parvin, S.M., Islam, M.A. and Saha, S. (2020) Microbial risk assessment of ready-to-eat mixed vegetable salads from different restaurants of Bangladesh Agricultural University campus. J. Adv. Vet. Anim. Res., $7(1): 34-41$.

12. CAC. (2010) Codex Alimentarius Commission Procedural Manual. World Health Organization and Food and Agricultural Organization of the United Nations, Rome, Italy.

13. Amoah, D. (2014) Microbial risk Assessment of Mixed Vegetable Salads from Selected Canteens in the Kumasi Metropolis, Ghana. MSc Thesis. Kwame Nkrumah University of Science and Technology, Ghana, Kumasi.

14. Rose, J.B. and Haas, C.N. (1999) A risk assessment framework for the evaluation of skin infections and the potential impact of antibacterial soap washing. Am. J. Infect. Control, 27(6): 26-33.

15. McCullough, N.B. and Elsele, C.W. (1951) Experimental human salmonellosis: Pathogenicity of strains of Salmonella meleagridis and Salmonella anatum obtained from spraydried whole egg. J. Infect. Dis., 88(3): 278-289.

16. Cornick, N.A. and Helgerson, A. (2004) Transmission and infectious dose of Escherichia coli O157: H7 in swine. Appl. Environ. Microbiol., 70(9): 5331-5335.

17. Zar, J.H. (1996) Biostatistical Analysis. $3^{\text {rd }}$ ed. Prentice Hall, Englewood Cliffs, New Jersey.
18. International Commission on Microbiological Specifications for Foods. (2002) Microorganisms in Foods 7: Microbiological Testing in Food Safety Management. US, Springer Publication.

19. Akusu, O.M., Kiin-Kabari, D.B. and Wemedo, S.A. (2016) Microbiological quality of selected street vended foods in Port Harcourt metropolis, Rivers State, Nigeria. Sky J. Food Sci., 5(2): 8-11.

20. Adimasu, A., Mekonmen, B., Guadu, T., Gizaw, Z. and Adane, T. (2016) Bacteriological quality assessment of selected street foods and their public health importance in Gondar Town, North West Ethiopia. Glob. Vet., 17(3): 255-264.

21. Khandoker, A., Islam, M., Rahman, M., Husna, A., Das, S. and Khatun, M. (2014) Bacterial contamination of streetvended spicy puffed-rice sold at Bangladesh Agricultural University campus. Bangladesh Vet., 31(1): 20-26.

22. Bereda, T.W., Emerie, Y.M., Reta, M.A. and Asfaw, H.S. (2016) Microbiological safety of street vended foods in Jigjiga city, Eastern Ethiopia. Ethiop. J. Health Sci., 26(2): 163-172.

23. Choudhury, M., Mahanta, L., Goswami, J., Mazumder, M. and Pegoo, B. (2011) Socio-economic profile and food safety knowledge and practice of street food vendors in the city of Guwahati, Assam, India. Food Control, 22(2): 196-203.

24. World Health Organization. (2006) Guidelines for the Use of Wastewater Excreta and Grey Water: Wastewater in Agriculture. World Health Organization, Geneva, Switzerland. 